\title{
BERTRAND RUSSELL'S WORK FOR PEACE [TO 1960]
}

\author{
Bertrand Russell and Edith Russell
}

Bertrand Russell may not have been aware of it, but he wrote part of the dossier that was submitted on his behalffor the Nobel Peace Prize. Before he had turned from the Campaign for Nuclear Disarmament to the Committee of Ioo and subsequent campaigns of the 196os, his wife, Edith, was asked by his publisher, Sir Stanley Unwin, for an account of his work for peace. Unwin's purpose is not known, but it is not incompatible with the next use of the document. Lady Russell responded:

You have set me a task which I am especially glad to do, and I enclose a screed made up of remarks which I have extracted (the word is deliberate!) from my husband since the arrival of your letter. If there is any more information about any part of his work for peace-which has been and is, much more intensive and absorbing than this enclosure sounds as if it wereI should be glad to provide it if I can and if you will let me know.

(7 Aug. 1960)

The dictation, and her subsequent completion of the narrative (at RAI 220.024190), have not previously been published, though the "screed" was used several times.

She had taken the dictation on 6 August 1960 and by next day had completed the account. Russell corrected her typescript by hand. Next we learn that Joseph Rotblat, Secretary-General of Pugwash, enclosed for her, on 2 March I96I, a copy of the "extracts" that were "sent to Norway" (RAI 625). The extracts were nearly the complete text, with the first person voice converted to the third. The timing and destination make it right for the deliberations of the Nobel Peace Prize committee. There are indications that Russell's name was submitted again in 1962 and again in 1963. None of this can be confirmed until the expiry of the Norwegian Nobel committee's rolling so-year embargo on its files. The prizewinners in 196I-63 were Dag Hammarskjöld, Linus Pauling, and the Red Cross. Russell promptly congratulated Pauling on his second Nobel prize.

Finally the document was retyped from Rotblat's copy and used in Into the Tenth Decade, the programme of tributes to Russell on his goth birthday. Edith added a list of Russell's speeches in I96I to the new typescript. Much of the document was the basis for much of the section "Bertrand Russell's Struggle for Peace", but with updates on 
his new struggles until May 1962 and a certain amount of rewriting. E.g., where Russell said he "protested vehemently" in 1926 when British soldiers fired upon unarmed crowds of Chinese students, the birthday document states that Russell "led protests" against the firing.

Did Bertrand Russell deserve the Nobel Peace Prize? This question devolves into whether he deserved it in 196I, for his work for peace since I955 (for the Manifesto, Pugwash and the Campaign for Nuclear Disarmament); in 1962 (for the addition of the Committee of Ioo and his related imprisonment in 196I); or 1963 (for his role in the Cuban Missile and Sino-Indian Crises). There is no sign that Russell's name was ever again submitted for the prize, though his work against the war in Vietnam and establishing the Peace Foundation (with its emphasis on international conciliation and the freeing of political prisoners that Amnesty wouldn't touch) constitute a remarkable supplement to the original account that follows. Russell didn't shy away from radicalsolutions, and doubtless his International War Crimes Tribunal was too controversial to be considered for the Peace Prize.-K.B.

\section{I}

have never been an absolute pacifist in the sense of condemning all wars. But nuclear weapons have made war so immeasurably more destructive than it used to be that I cannot now think any war in which both sides have nuclear weapons justifiable. And, moreover, any war is likely to become a nuclear war. For practical purposes, therefore, my present position differs very little from that of an absolute pacifist. ${ }^{\text {I }}$

\section{FIRST WORLD WAR}

My opposition to the First World War began in 1902 when I heard Sir Edward Grey advocate the, as yet unadopted, policy of the Entente, to which I was and remained vehemently opposed as a policy obviously leading to war. The occasion when I first heard him advocate this policy was at a meeting of a small debating society to which we both belonged. I opposed the policy hotly then and continued to argue ${ }^{2}$ against it when-

I [In the manuscript dictated to Edith Russell but omitted from the typescript:]

Boer War I899-I902. I regret to say that I was, at first, in favour of the Boer War, but I changed my opinion owing to the cruelties of the Concentration Camps which the British invented in that war, thus setting an example to Nazis and Communists.

${ }^{2}$ [Russell corrected the typing of this word from "agree".] 
ever possible.

In 19I4, in the last days before the outbreak of war, I collected signatures in favour of British neutrality.

After war broke out, I continued to oppose it. Before the Germans in this country were interned, I joined an organization to relieve hardship amongst them where necessary.

I worked in conjunction with the newly founded Union of Democratic Control, writing pamphlets and making speeches for them. They were an organization brought into being to protest against secrecy in foreign policy, which had committed Britain to war without the knowledge of the public, or even most of the Cabinet.

I was over military age, but I supported the Conscientious Objectors and became Acting Chairman of their organization after almost all of them had been sent to gaol.

I spoke against the war in many places, including the industrial regions of South Wales, with the result that the Government forbade me to go anywhere near the coast (lest I signal to German submarines).

I supported, in articles and speeches, possible reasonable terms of peace. While America was still neutral, I wrote a letter to President Wilson, which was smuggled out of Britain and published in most of the American newspapers, urging the President to act as arbitrator.

I wrote Justice in War Time in 1915; The Policy of the Entente in 1915; Principles of Social Reconstruction in 1916 followed by Roads to Freedom in 1918.

My opposition to the war led to my being deprived of my Lectureship at Cambridge in 1916 and to my being imprisoned in 1918. I was imprisoned for quoting the official Report of a Senatorial Investigation that pointed out that the American army was used on occasion to break strikes and for suggesting the danger of similar action here.

\section{I920-JOURNEY TO RUSSIA}

I went with a Labour Delegation sent in the hopes of establishing friendly relations with the new Russian Government. I did not like the Communist system, but I thought it highly desirable to recognize the Russian Government and have diplomatic relations with it (just as I now urge the necessity of including China in the U.N.). Both these points of view I set forth in Bolshevism in Practice and Theory in 1920.

1920-2I - in China (The Problem of China, 1922). 
I926- When British soldiers fired upon unarmed crowds of Chinese students, I protested vehemently.

(Work in favour of Indian Independence. President of the India League.)

\section{THE SECOND WORLD WAR}

In 1930's I remained in favour of peace until shortly before the outbreak of the Second World War when I became convinced that peace with Hitler was impossible. I remained aloof from politics, although I did a certain amount of speaking and writing in support of the war and in preparation for the hoped-for peace after the war, until the menace of atomic war became imminent.

\section{AFTER THE SECOND WORLD WAR}

1945-50-While America had a monopoly of atomic weapons, I favoured the Baruch Plan, which would have entailed their abandonment by the United States and an undertaking by Russia to abstain from making them. When Russia refused to adhere to the Baruch Plan, I thought that the United States could compel adherence, if necessary by the threat of war (I never urged this publicly, but only stated this view in private correspondence - since published - and conversation).

I spoke in the House of Lords on the importance of banning atomic weapons and warned of the possibility of $\mathrm{H}$-bombs, which had not then been invented.

\section{$1950 s^{3}$}

Since each side has had H-bombs, I have increasingly devoted my energies to the improvement of relations between Russia and the West, and to obtaining agreements abolishing nuclear weapons. I have tried to inform the Public of the dangers and to persuade them to adopt and support measures, differing, naturally, in different circumstances, which were likely to mitigate the dangers.

1954, December 23-I gave a Christmas Broadcast entitled "Man's

${ }^{3}$ Ghost-written - E. R. — from here on. My husband would never be so long-winded. 
Peril" over the ввс. This was printed by various organizations and distributed as a leaflet. It was also reprinted as an article in various papers in many different countries, and was published in Portraits from Memory. Because of the wide and favourable response that I received, I determined to draw up a manifesto to send to various eminent scientists of whom I knew in countries on both sides of the Iron Curtain asking them to sign it. Among these was Einstein, who supported my idea and said that he would gladly help but was too ill to do much. I drew up the manifesto basing it upon Man's Peril and obtained ten signatures to it (besides my own), including those of both Western and Communist scientists. This was, I believe the first pronouncement concerning nuclear weapons in which scientists - or indeed any persons - of both East and West collaborated. It seemed to me necessary that the public should realize that the dangers of nuclear weapons were recognized by eminent scientists, both Eastern and Western. I therefore wished to do something dramatic to call the public's attention to this pronouncement, but I did not know how to manage it. With the advice of The Editor of The Observer and members of his staff, especially Mr. Kenneth Harris, I determined to hold a Press Conference to which representatives of all newspapers both British and foreign who had representatives in London should be invited. This was done, and was largely made possible by the help of The Observer.

The Press Conference was held on 9 July 1955, in the large room of the Caxton Hall, Westminster. It was attended by reporters from all the newspapers who had been invited, by wireless men and T.v. men. I read the manifesto and the names of the signatories, and then for two hours answered the questions asked me by the reporters on matters relating to the pronouncement. The news of the manifesto, and usually the manifesto itself, was published in most of the countries of the world. The manifesto is usually referred to as the Einstein-Russell Pronouncement, for though Einstein had had nothing more to do with it than any of the other signatories whose names I obtained, his name was of great "news value" and the circumstances of his signing it were dramatic, since almost the last letter that he wrote was the letter in which he agreed to sign it which I received after receiving the news of his death.

Many people wrote urging me to carry the work of the manifesto further and organize a conference to which scientists of both East and West should be invited to discuss, and if possible agree on, the hazards of nuclear weapons. With the help of Professor Powell and Professor 
Burhop and, especially, Professor J. Rotblat, who had been the Chairman of the Press Conference of 9 July 1955, such a conference was organized. Mr. Cyrus Eaton had written me offering to finance or help to finance such a conference. He now agreed to do so if the conference were held at his estate, Pugwash, in Nova Scotia, and were called The Pugwash Conference. The first of the Pugwash Conferences was held at Pugwash on 6-IO July 1957 and was attended by scientists from both East and West. It was, I believe, the first of conferences to be held among members from both East and West that was not governmental and Official. From this conference has grown The Pugwash Movement, of which I am the President and Professor Rotblat is the Secretary and which has a standing committee composed of members of both East and West. It has now held, in all, five conferences on various aspects of the dangers at present confronting mankind owing to the advance of science and technology, attended by scientists whose work is relevant to the chief topics under discussion at any particular meeting. A Report has been drawn up of each conference and has been published, but has not had nearly adequate publicity. The scientists of both East and West have agreed unanimously upon these reports and have been able to come to unanimous resolutions (in only one case, I believe was there a dissentient voiceand that only one, an American). Another conference is expected to take place at Moscow in September and then, shortly, another in the United States.

A description of the nature and aims of the Pugwash Movement which the Movement has printed is: "The Pugwash Movement is a spontaneous movement in which scientists from many nations come together in periodic conferences, without direct government control, representing nobody, and solely as individuals, to consider the rôle of the scientist in contemporary life and to discuss means whereby science can be devoted to constructive purposes and not destructive ones.

"It has three general aims: I. To act as a channel of communication between scientists all over the world about the social consequences of the advance of science. 2. To inform governments from time to time of those means of lessening the risk of war and increasing the benefits to mankind from science which it agrees are possible. 3. To educate public opinion on the same matters."

During the time, and after, I was working on the Russell-Einstein pronouncement from which the Pugwash Movement took its immediate source, I did considerable work for the Parliamentary World Govern- 
ment Association, speaking for them at various meetings and taking part - speaking at both private meetings and meetings open to the public: in the World Government Association and the Parliamentary Union joint Congress at Rome after Easter, 1955 and following it, at Paris; at the World Government Conferences at Paris, 29 July ff., I955; and at their Congress (which was, I believe their first attended by Russians) in London, 3-5 August 1955; etc. I think that a world Government having a monopoly of the major weapons of war is the only ultimate solution if the human race is to survive.

During the last years I have made as many speeches, ${ }^{4}$ messages and articles for organizations and papers as I could in both Western and Communist countries 5 and in the Far East and Africa and in Uncommitted countries in order to publicize the dangers and to make what seemed to me useful suggestions as to how they might be mitigated or avoided. Articles have been published in Moscow, as well as in Czechoslovakia, Jugoslavia, Poland, etc.

I have done as much work as possible for the Campaign for Nuclear Disarmament, and its various branches, of which I am the President. I take any occasion that I can to make use of the publicity given by wireless and, especially T.v.

I wrote an Open Letter to Krushchev and Eisenhower which was published with replies as a book called The Vital Letters of Russell, Krushev, Dulles.

I wrote Common Sense and Nuclear Warfare, which has been published in many countries.

I have urged, at various times, ${ }^{6}$ and especially since the break-down of

4 [Here Edith Russell wrote above the line, "Do you want chapter and verse here? There are so many!" Presumably she addressed this to Stanley Unwin.]

5 [Marginal note: "Articles have been published in Moscow as well as in Czechoslovakia, Jugoslavia, Poland etc.”]

${ }^{6}$ [Edith added below this paragraph:]

(My husband has been in close touch with various anti-nuclear organizations and persons in Germany-I believe I once showed you some documents about this connection. Articles of his have been published in Germany especially in the Hamburg Kongressdienst and the Munich(?) Die Kultur. He is an Honorary Member of the Verband der Kriegsdienstverweigerer which held its annual meeting at Detmold last May. They sent him a telegram: "The Annual Meeting 1960 of the Verband der Kriegsdienstverweigerer assembling this weekend at Detmold Germany sends its greetings to its Honorary member Bertrand Russell. The discussion and general 
the Summit Meeting, the Uncommitted nations to come to the rescueto put forward compromise suggestions which could be discussed and, without loss of face, agreed to by both sides. ${ }^{7}$

opinion of the meeting is more than ever based on your political and ethical views. Thanks for all your activity.)

P.S.: You remember that the Grotius Stiftung gave him a prize a year or two ago? They have just made him a member of their International Praesidium.

7 [Edith added in 1961 or 1962:]

In 196I Made Speeches:

In Trafalgar Square, Feb., for Comm. of 100

In Birmingham for CND

In Birmingham for YCND

In Trafalgar Sq. for CND (Aldermaston)

In Hyde Park-Trafalgar Sq. for Committee of 100

Various Speeches in re prison for Committee of IOO

At Cardiff for CND

N.B. Note that he has made rather more speeches for CND or YCND than for Comm.! 